\title{
MOLECULAR SURVEY OF AVIAN RESPIRATORY VIRUSES IN COMMERCIAL BROILER AND LAYER FLOCKS WITH RESPIRATORY MANIFESTATIONS IN KAFRELSHEIKH GOVERNORATE
}

\author{
Moshira A. El-abassy"; Samy Kasem "; El-Bagoury G. Fekry "." \\ and Asmaa F. Magouz" \\ * Departement of Poultry Diseases, Faculty of Veterinary Medicine, \\ Kafr El-Sheikh University \\ ** Departement of Virology, Faculty of Veterinary Medicine, \\ Kafr El-Sheikh University \\ "*" "Departement of Virology, Faculty of Veterinary Medicine, Banha University
}

\begin{abstract}
Acute respiratory tract infections are generally the main hazard to the poultry industry in Egypt leading to severe economic losses. The present study was aimed to standardize a multiplex polymerase chain $(m P C R)$ reaction that simultaneously detects and differentiates the four major avian respiratory viruses (AIV, NDV, IBV and ILTV) in single reaction, as well as to apply a molecular survey of avian respiratory viruses in commercial broiler and layer flocks suffering from respiratory manifestations with relatively high mortality rate in different localities of Kafrelsheikh governorate using the standardized MPCR assay. The obtained results indicate the high occurrence of mixed infections among these viruses which makes it difficult to differentially diagnose these diseases by clinical manifestations.
\end{abstract}




\section{INTRODUCTION}

Poultry sector is one of the most important segments of the agriculture sector in Egypt, where investment in this industry is about 20 billion Egyptian pounds (El Nagar and Ibrahim 2005). This sector has faced serious challenges through respiratory viral infections (AbdelWhab and Hafez 2011). The etiology of the respiratory disease is complex, often involving more than one pathogen. Several avian viruses have a predilection for the respiratory tract of chickens: Avian Influenza virus (AIV), Newcastle disease virus (NDV), Infectious bronchitis virus (IBV) and Infectious laryngotracheitis virus (ILTV) primarily infect the respiratory tract of chickens (Roussan et al., 2008). These viruses are of major importance because they can cause disease independently, in association with each other or in association with other bacterial or viral pathogens (Ali and Reynolds 2000). Unfortunately, due to very close resemblance of lesions produced by several other pathogens in poultry, it is difficult to differentially diagnose clinical manifestations of AI infections from diseases such as ND, IB and ILT (Rashid et al., 2009). Additionally, mixed infections may occur due to extensive use of multiple live vaccines, high geographic populations and housing densities (Pang et al., 2002). Therefore, it becomes essential to develop a rapid and sensitive diagnostic technique to detect and differentiate between these diseases which is very important for the control of the disease transmission in poultry and humans (Rashid et al., 2009).

A multiplex polymerase chain reaction (mPCR) technique that simultaneously detects and differentiates the four major avian respiratory 
viruses in a single reaction, will be highly advantageous to the poultry industry and would greatly aid in the diagnosis and control of outbreaks because it offers rapid and specific detection of these viruses without the need for subculture in host system which is laborious and time consuming and cause risk from handling the infectious materials (Spackman et. al., 2002). Additionally, it eliminates the need to test clinical samples separately for each virus (Yashpal et al., 2004) and results are generally available within few hours as compared with virus isolation (VI) technique which requires about 4-5 days or sometimes more for definitive diagnosis (Tao et al., 2009). Furthermore, it provides better detection of the virus from the clinical samples which might appear negative due to inappropriate sampling or loss of infectivity during shipment (Siddique et al., 2008).

In this study we record a molecular survey of the most important avian respiratory viruses through field samples collected from broiler and layer chicken flocks in Kafrelsheikh governorate during the period from October 2011 till February 2013 using a rapid multiplex PCR technique which detects and differentiates the four major avian respiratory viruses (AIV, IBV, NDV and ILTV) in a single reaction.

\section{MATERIAL AND METHODS}

\section{Source and collection of samples:}

A total of 100 fresh post mortem (P. M.) tissue samples including lungs, tracheas, and proventriculas were collected from broiler and layer chicken farms suffered from severe respiratory manifestations and 
relatively high mortality rate from different localities in Kafrelsheikh governorate during the period from October 2011 till February 2013.Samples were immediately transported on ice to the Central Diagnostic and Research Lab, Faculty of Veterinary Medicine, Kafrelsheikh University and stored at $-80^{\circ} \mathrm{C}$ till used.

\section{Viruses and Vaccines:}

These viruses were used as reference control positive during development of multiplex PCR tests:

a) Avian Influenza serotype $\mathrm{H} 5 \mathrm{~N} 2$ infected allantoic fluid was kindly supplied by Animal Health Research Institute, Dokki, Giza, Egypt.

b) Izovac IB-H120. Freeze-dried live attenuated vaccine against Infectious Bronchitis serotype Massachusetts H120. (Izo S.p.A. Italy).

c) Fowl Laryngeotracheitis. Freeze-dried live attenuated vaccine. LTIVAX. Shering-Plough Animal Health Corp. (Nebraska USA)

d) NDVvaccine. Freeze-dried live attenuated vaccine against Newcastle disease (Lasota) (HIPRA Laboratories, Girona, Spain).

\section{RNA extraction:}

RNA was extracted from AI infected allantoic fluid, IBV and NDVvaccines and field samples using Trizol Easy-Red ${ }^{\mathrm{TM}}$ Total RNA extraction Kit (Intron Biotechnology) as per manufacturer's protocol. Briefly, $500 \mu \mathrm{l}$ of infected allantoic fluid or vaccines were mixed with $750 \mu \mathrm{l}$ of TRI reagent followed by centrifugation at $10,000 \mathrm{rpm}$ for 10 min. The supernatant was transferred to a fresh diethyl pyrocarbonate 
(DEPC) treated tube and added with $200 \mu \mathrm{l}$ of chilled chloroform. The mixture was left at room temperature for $15 \mathrm{~min}$. and centrifuged at $10,000 \mathrm{rpm}$ for $15 \mathrm{~min}$. at $4^{\circ} \mathrm{C}$. The upper aqueous phase was then transferred to a fresh tube and $500 \mu$ of chilled isopropanol was added followed by centrifugation at $10,000 \mathrm{rpm}$ for $10 \mathrm{~min}$. at $4{ }^{\circ} \mathrm{C}$. The supernatant was discarded and the pellet was first washed with $100 \%$ followed by $70 \%$ ice-cold ethanol. Finally the pellet was re-suspended in $30 \mu \mathrm{l}$ RNAse free water and stored at $-80^{\circ} \mathrm{C}$ for further analysis. Moreover, the extracted RNA was analyzed for its quality and quantity using Nano-drop method. Briefly, the equipment was first activated with $2 \mu \mathrm{l}$ of RNA/DNA free water. Later the same amount of sample was placed on the machine pedestal and the setting for"RNA" selected. The system measures the quality and quantity of RNA in the given sample.

\section{Reverse transcription of extracted RNA to cDNA:}

The reverse transcription (RT) of the extracted RNA to cDNA was performed using Maxime ${ }^{\mathrm{TM}}$ RT PreMix Kit (Gene On) with oligo (dt)18 primers. Briefly, a mixture of $5 \mu$ l of extracted RNA, $1 \mu \mathrm{l}$ of Oligo dT and $2 \mu \mathrm{l}$ of Sterile RNAs free water were prepared and incubated at 70 ${ }^{\circ} \mathrm{C}$ for $10 \mathrm{~min}$, then placed on ice for $5 \mathrm{~min}$. Another mixture of $4 \mu \mathrm{l} \mathrm{X}$ reaction buffer, $1 \mu \mathrm{dNTP} \operatorname{mix}(10 \mathrm{mM}$ of each $=40 \mathrm{mM}), 1 \mu 1$ RNAs inhibitor, $1 \mu \mathrm{l}$ MMLV Reverase $(200 \mathrm{u} / \mu \mathrm{l})$ and $13 \mu \mathrm{l}$ sterile RNAse free water. Mix I and Mix II were combined, gently vortexed and incubated in heat block at $55^{\circ} \mathrm{C}$ for $90 \mathrm{~min}$, then at $70^{\circ} \mathrm{C}$ for $10 \mathrm{~min}$. for inactivation of the enzyme. cDNA was stored at $-20^{\circ} \mathrm{C}$ for further applications. 


\section{DNA extraction from field samples and ILTV vaccine:}

The DNA was extracted using Gene Jet ${ }^{\mathrm{TM}}$ Genomic DNA purification Kit, Fermentas International Inc. as per manufacturer's protocol.Briefly; $20 \mathrm{mg}$ of tissue were grinded in liquid nitrogen using a mortar and pestle. The grinded material was resuspend in $180 \mu \mathrm{l}$ of Digestion Solution and $20 \mu \mathrm{l}$ of proteinase K Solution. The sample was incubated at $56^{\circ} \mathrm{C}$ until the tissue is completely lysed. $20 \mu \mathrm{l}$ of RNase A Solution were added, incubated for $10 \mathrm{~min}$ at room temperature. $200 \mu \mathrm{l}$ of lyses solution were added and mixed by vortex .Then $400 \mu 1$ of $50 \%$ ethanol were added and mixed.The prepared lysate was transferred to a Gene JET ${ }^{\text {TM }}$ Column inserted in a collection tube, centrifuged for $1 \mathrm{~min} /$ 6000xg. $500 \mu \mathrm{l}$ of Wash Buffer I were added and centrifuged for $1 \mathrm{~min} /$ $8000 \mathrm{xg}$.Then $500 \mu \mathrm{l}$ of Wash Buffer II were added and centrifuged for 3 min at $(\geq 12000 \mathrm{xg})$. The Gene JET ${ }^{\mathrm{TM}}$ Column was transferred to a sterile $1.5 \mathrm{ml}$ micro centrifuge tube and $200 \mu \mathrm{l}$ of Elution Buffer were added to the center of the Gene JETTM Column membrane to elute genomic DNA .The purified DNA was stored at $-20{ }^{\circ} \mathrm{C}$ for further applications.

\section{Primer designs:}

Four sets of oligonucleotide primers that specifically amplify type A influenza virus (Matrix protein gene), S1 gene of IBV, F protein gene of NDV and ILTV were commercially synthesized by (Metabion international AG, Germany) and listed in table 1.The primers were aliquot to a final concentration of $50 \mathrm{pmol}$ and stored at $-20^{\circ} \mathrm{C}$ until use. The functionality and specificity of all primer were tested in single reactions before combining them in a multiplex PCR assay. 
Moshira A. El-abassy et., al.

Table (1): Oligonucleotide primers used in this study

\begin{tabular}{|c|c|c|c|c|}
\hline $\begin{array}{l}\text { Primer } \\
\text { name }\end{array}$ & Oligonucleotide sequence & Target gene & $\begin{array}{c}\text { Length of } \\
\text { amplified fragment }\end{array}$ & Reference \\
\hline $\begin{array}{l}\text { IBV-F } \\
\text { IBV-R }\end{array}$ & $\begin{array}{c}\text { GCTTTT GAG CCT AGC GTT } \\
\text { GCC ATGTTGTCACTGTCT ATT }\end{array}$ & S1 gene & $149 \mathrm{bp}$ & Callison et.al 2006 \\
\hline $\begin{array}{l}\text { NDV-F } \\
\text { NDV-R }\end{array}$ & $\begin{array}{l}\text { GGAGGATGT TGGCAGCAT T } \\
\text { GTCAACATATACACCTCATC }\end{array}$ & S1 gene & $320 \mathrm{bp}$ & Pang et.al 2002 \\
\hline $\begin{array}{l}\text { ILTV-F } \\
\text { ILTV-R }\end{array}$ & $\begin{array}{l}\text { ACGATGACTCCGACTTTC } \\
\text { CGTTGGAGGTAGGTGGTA }\end{array}$ & & $647 \mathrm{bp}$ & Pang et.al 2002 \\
\hline $\begin{array}{l}\text { AIV-F } \\
\text { AIV-R }\end{array}$ & $\begin{array}{c}\text { CTTCTAACCGAGGTCGAAACG } \\
\text { AGGGCATTTTGGACAAAGCGTCTA }\end{array}$ & M gene type A & $244 \mathrm{bp}$ & Xie et.al 2006 \\
\hline
\end{tabular}

\section{Multiplex PCR reaction:}

The mPCR technique was optimized using RNA and DNA extracted from live attenuated vaccines for NDV, IBV and ILTV . While RNA of AIV was extracted from infected allantoic fluid. It was performed in $50 \mu \mathrm{l}$ volumes, in which the reaction mixture consisted of $10 \mu \mathrm{l}$ of $5 \mathrm{X}$ Master Mix (Taq/High Yield-Jena Bioscience, Jena, Germany) (5X Conc.of thermostable DNA Polymerase, dATP, dCTP, dGTP, dTTP, (NH4)SO4, MgCl, Tween 20, Noniodet P-40, stabilizers), $1 \mu \mathrm{l}$ of forward and reverse primers of each virus, $5 \mu 1$ of cDNA,5 $\mu 1$ of DNA and $22 \mu$ l of PCR grade water. The mPCR was performed in Bio Rad T100 thermal cycler.The cycling protocol consisted of initial denaturation at $96^{\circ} \mathrm{C}$ for $5 \mathrm{~min}$. followed by 40 cycles of denaturation at $95^{\circ} \mathrm{C} / 1 \mathrm{~min}$, annealing at $53{ }^{\circ} \mathrm{C} / 1 \mathrm{~min}$ and extension at $70^{\circ} \mathrm{C} / 1 \mathrm{~min}$. with a final extension at $72{ }^{\circ} \mathrm{C} / 10 \mathrm{~min}$. Throughout the development of the mPCR, many modifications were applied to the annealing temperature, extension time and the number of cycles. A negative control containing only PCR master mix, primers and PCR grade water was also included. 


\section{Detection of PCR product by gel electrophoresis:}

PCR products were analyzed by agarose gel electrophoresis using $2 \%$ agarose. Amplified products were visualized by ultraviolet light transillumination after staining with $0.1 \mu \mathrm{g} / \mathrm{ml}$ ethidium bromide. A 100 bp ladder (GeneON, GmbH, Germany) was used as a molecular weight marker.

\section{RESULTS}

The mPCR technique was succssesfully able to amplify specific genes of AIV, NDV, IBV and ILTV with expected product size of 244 bp, 320 bp, 149 bp and 647 bp respectively in one single reaction which were visualized by agarose gel electrophoresis. Only the target sequences were amplified and no non specific PCR products were noticed. Negative control sample (containing only buffer system and primers) was negative.

To validate the use of these mPCR assays in field samples, it was applied on 100 field samples collected from broiler and layer chicken flocks suffering from severe respiratory signs and relatively high mortality in Kafrelsheikh governorate.

The total number of positive samples was 61 out of 100 examined samples $(61 \%)$. The number of samples with single viral infection was 45 sample with a percentage of (45\% from total samples) and $(73.7 \%$ from positive samples) while number of samples with mixed viral infection was 16 sample (16\% from total samples) and (26.3\% from positive samples).15 samples were mixed infections with two different viruses while only one sample contained mixed infection with 3 viruses.

The total number of samples positive for AIV infection was 30 samples (30\% from total samples) and (49.1\% from positive samples) ,16 
of them were single infection while in 14 samples it was combined with other viruses (8 samples co infected with IBV, 5 samples co infected with NDV and 1 sample mixed with both IBV and NDV.)

The total number of positive samples for IBV infection was 25 samples out of 100 examined samples (25\% from total samples) and (40 $\%$ from positive samples).14 of the were single IBV infection while in 11 samples it was mixed with other viruses ( 8 samples with AIV, 2 samples with NDV and one samples was mixed with both AIV and NDV).

NDV was detected in 23 samples out of 100 collected samples (23\% from total samples) and (37.7\% from positive samples). 15 of them were single NDV infection while in 8 samples it was mixed with other viruses (5 samples with AIV, 2 samples with IBV and in one samples it was combined with both AIV and IBV). While ILTV could not be detected in this study.

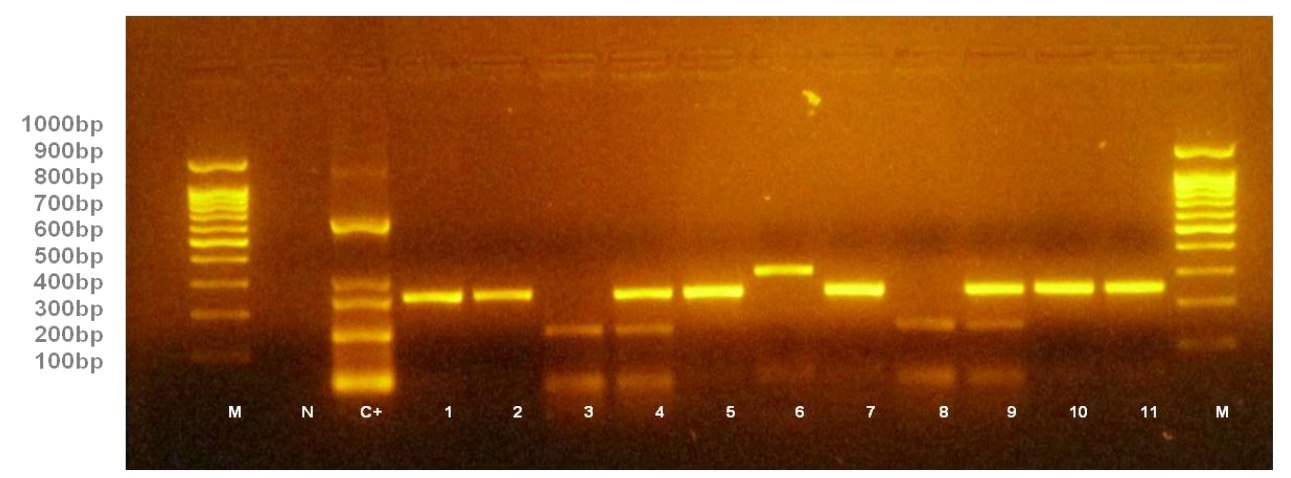

Fig. (1): Agarose gel electrophoresis of multiplex PCR amplified products for purified RNA and DNA of field samples. Lane M; 100 bp DNA size marker. Lane N; Negative control. Lane C;positive control .Lane 1, AIV, Lane 2; AIV.Lane 3;IBV. Lane 4; IBV+AIV. Lane 5;AIV.Lane 6;NDV.Lane 7;AIV.Lane 8;IBV.Lane 9;IBV+AIV.Lane 10;AIV. Lane 11; AIV. 


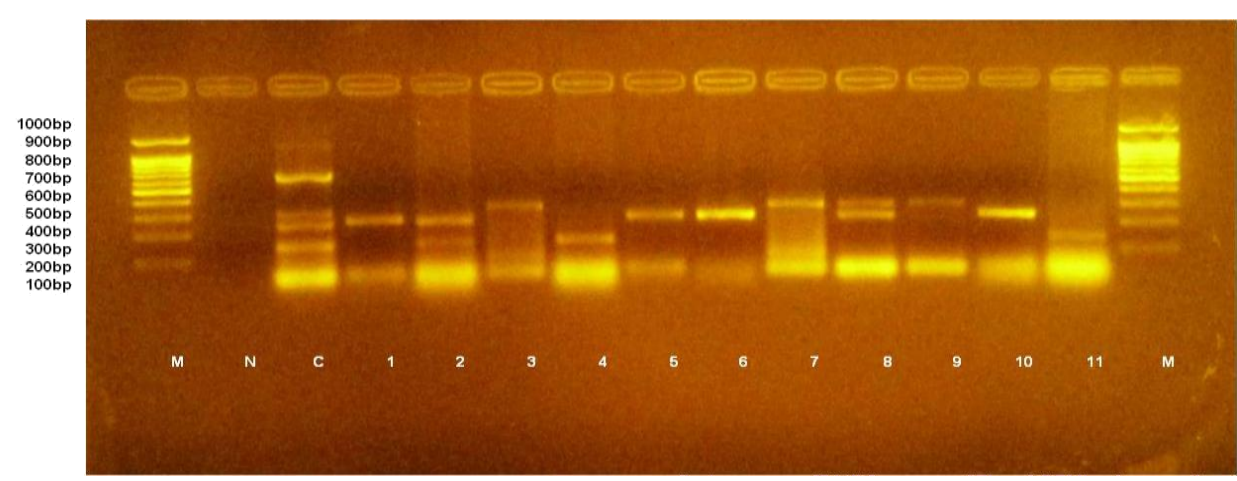

Fig. (2): Agarose gel electrophoresis of multiplex PCR amplified products from purified RNA and DNA of field samples. Lane M ;100 bp DNA size marker. Lane $\mathrm{N}$; Negative control .Lane 1,AIV, Lane 2; AIV+IBV.Lane 3;NDV. Lane 4; IBV. Lane 5; AIV. Lane 6; AIV.Lane 7; NDV.Lane 8; AIV+NDV.Lane 9; NDV .Lane 10; AIV. Lane 11; IBV.

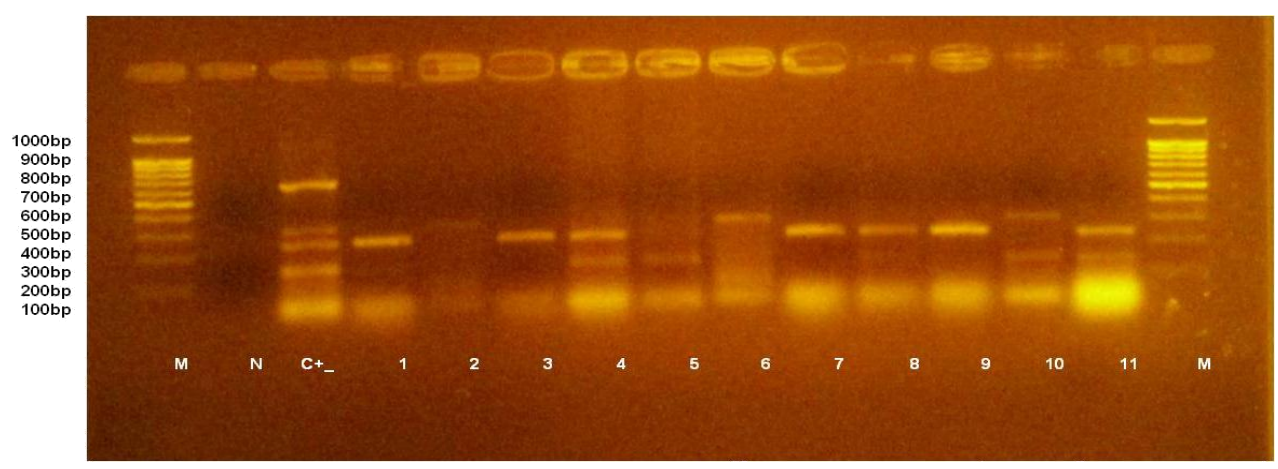

Fig. (3): Agarose gel electrophoresis of multiplex PCR amplified products from purified RNA and DNA of field samples. Lane M; 100 bp DNA size marker. Lane $\mathrm{N}$; Negative control .Lane 1,AIV, Lane 2; NDV.Lane 3;AIV. Lane 4; IBV+AIV. Lane 5; IBV. Lane 6; NDV.Lane 7; AIV.Lane 8;AIV.Lane 9;AIV .Lane 10;NDV+IBv. Lane 11; IBV+AIV. 


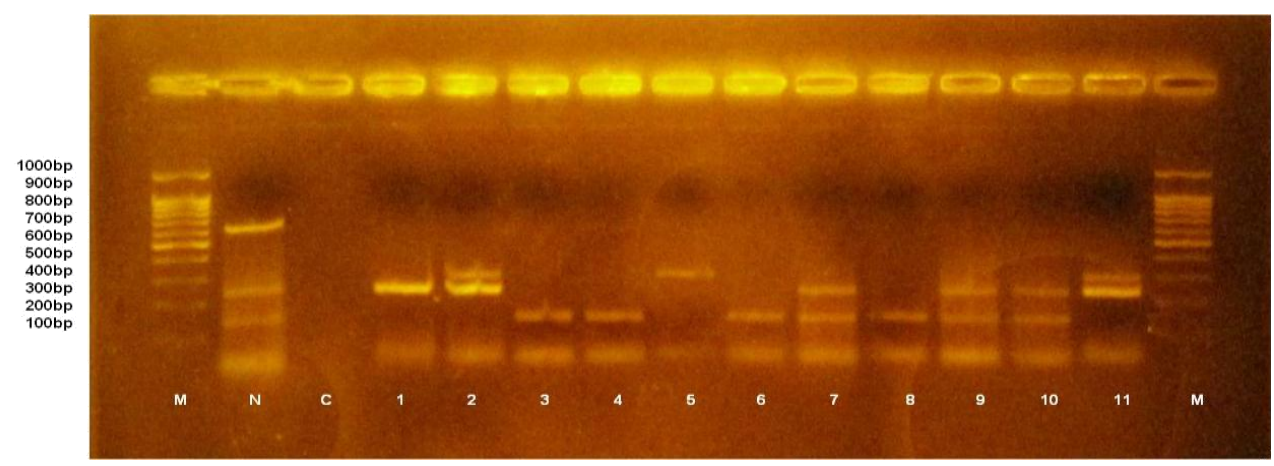

Fig. (4): Agarose gel electrophoresis of multiplex PCR amplified products from purified RNA and DNA of field samples. Lane M; 100 bp DNA size marker. Lane N; Negative control .Lane 1, AIV, Lane 2; AIV+ NDV. Lane 3; IBV. Lane 4; IBV. Lane 5; NDV. Lane 6; IBV.Lane 7; AIV +IBV.Lane 8; IBV.Lane 9; AIV+IBV .Lane 10; AIV+IBV. Lane $11 ; \mathrm{IBV}+\mathrm{NDV}$.

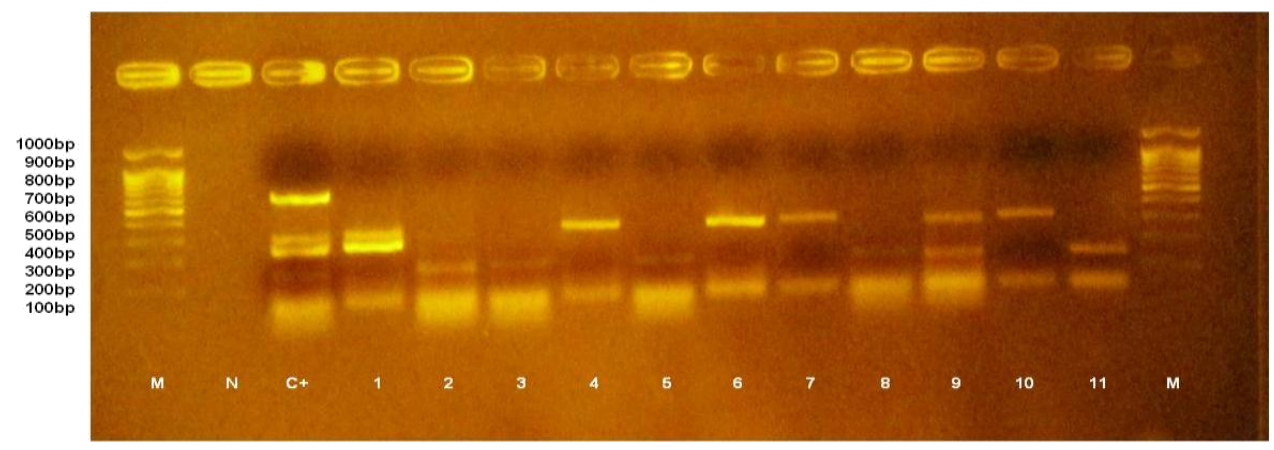

Fig. (5): Agarose gel electrophoresis of multiplex PCR amplified products from purified RNA and DNA of field samples. Lane M; 100 bp DNA size marker. Lane N; Negative control .Lane 1, AIV+NDV, Lane 2; IBV.Lane 3; IBV. Lane 4; NDV. Lane 5; IBV. Lane 6; NDV.Lane 7; NDV.Lane 8; IBV.Lane 9; NDV+IBV .Lane 10;NDV. Lane 11; IBV. 
Moshira A. El-abassy et., al.

Table (2): Multiplex PCR results of field samples collected from Kafrelsheikh governorate.

\begin{tabular}{|c|c|c|c|c|c|c|c|}
\hline $\begin{array}{l}\text { Type of respiratory } \\
\text { viral infection }\end{array}$ & \begin{tabular}{|c} 
Total No. of \\
examined \\
samples
\end{tabular} & $\begin{array}{l}\text { No. of } \\
\text { positive } \\
\text { samples }\end{array}$ & $\%$ & $\begin{array}{l}\text { Type frespiratory } \\
\text { viral infection }\end{array}$ & $\begin{array}{c}\text { Total No. of } \\
\text { examined } \\
\text { samples }\end{array}$ & $\begin{array}{c}\text { No. of } \\
\text { positive } \\
\text { samples }\end{array}$ & $\%$ \\
\hline $\begin{array}{c}\text { AIV } \\
\text { (total number of AIV) }\end{array}$ & 100 & 30 & $30 \%$ & $\begin{array}{c}\text { IBV+NDV } \\
\text { (mixed infection) }\end{array}$ & 100 & 2 & $2 \%$ \\
\hline $\begin{array}{c}\text { IBV } \\
\text { (total number of IBV) }\end{array}$ & 100 & 25 & $25 \%$ & $\begin{array}{c}\text { AIV+NDV } \\
\text { (mixed infection) }\end{array}$ & 100 & 5 & $6 \%$ \\
\hline $\begin{array}{c}\text { NDV } \\
\text { (total number of } \\
\text { NDV) }\end{array}$ & 100 & 23 & $23 \%$ & $\begin{array}{l}\text { AIV+NDV+IBV } \\
\text { (mixed infection) }\end{array}$ & 100 & 1 & $1 \%$ \\
\hline $\begin{array}{c}\text { AIV } \\
\text { (single infection) }\end{array}$ & 100 & 16 & $16 \%$ & ILTV infection & 100 & 0 & $0 \%$ \\
\hline $\begin{array}{c}\text { IBV } \\
\text { (single infection) }\end{array}$ & 100 & 14 & $14 \%$ & $\begin{array}{l}\text { Total number of } \\
\text { positive samples }\end{array}$ & 100 & 61 & $61 \%$ \\
\hline $\begin{array}{c}\text { NDV } \\
\text { (single infection) }\end{array}$ & 100 & 15 & $15 \%$ & $\begin{array}{l}\text { Total number of } \\
\text { mixed infections }\end{array}$ & 100 & 16 & $16 \%$ \\
\hline
\end{tabular}

Table (3): The incidence of mixed infections in the examined field samples detected by mPCR assay in relation to the total number of positive samples:

\begin{tabular}{||c||c||c||c||}
\hline $\begin{array}{c}\text { Type of mixed } \\
\text { infection }\end{array}$ & $\begin{array}{c}\text { Number of positive } \\
\text { samples }\end{array}$ & $\begin{array}{c}\text { Total number of } \\
\text { positive samples }\end{array}$ & $\begin{array}{c}\text { Percentage in relation to total } \\
\text { number of positive samples (61) }\end{array}$ \\
\hline \hline AIV +IBV & 8 & 61 & $13.1 \%$ \\
\hline AIV +NDV & 5 & 61 & $8.1 \%$ \\
\hline IBV+ NDV & 2 & 61 & $3.2 \%$ \\
\hline AIV+IBV+NDV & 1 & 61 & $1.6 \%$ \\
\hline
\end{tabular}

Table (4): The incidence of mixed infections in the examined samples detected by $\mathrm{mPCR}$ assay in relation to the total number samples with mixed infections:

\begin{tabular}{|c||c||c||c||}
\hline $\begin{array}{c}\text { Type of mixed } \\
\text { infection }\end{array}$ & $\begin{array}{c}\text { Number of positive } \\
\text { samples }\end{array}$ & $\begin{array}{c}\text { Total number of samples } \\
\text { with mixed infections }\end{array}$ & $\begin{array}{c}\text { Percentage in relation to number } \\
\text { of samples with mixed infections }\end{array}$ \\
\hline \hline AIV +IBV & 8 & 16 & $50 \%$ \\
\hline AIV +NDV & 5 & 16 & $31.25 \%$ \\
\hline IBV+ NDV & 2 & 16 & $12.5 \%$ \\
\hline AIV+IBV+NDV & 1 & 16 & $6.25 \%$ \\
\hline
\end{tabular}

$\overline{\text { Kafrelsheikh Vet. Med. J. Vol. } 11 \text { No. } 1 \text { (2013) }}$ 


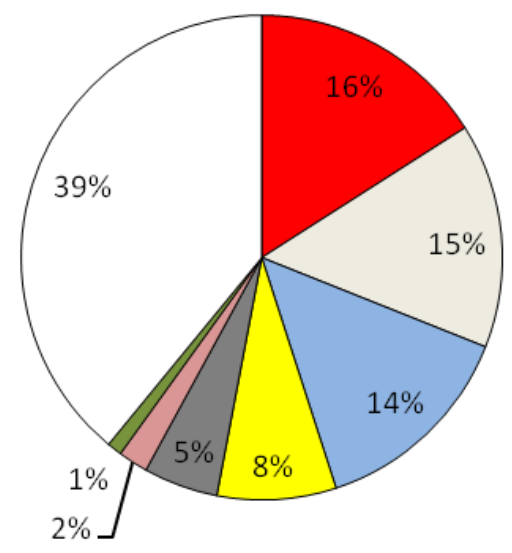

$\square \mathrm{Al} \square \mathrm{ND} \square \mathrm{IB} \square \mathrm{Al}+\mathrm{IB} \square \mathrm{Al}+\mathrm{ND} \square \mathrm{IB}+\mathrm{ND} \square \mathrm{Al}+\mathrm{ND}+\mathrm{IB} \square$ Negative

Fig. (7): Percentage of detected respiratory viral infections in relation to the total number of examined samples.

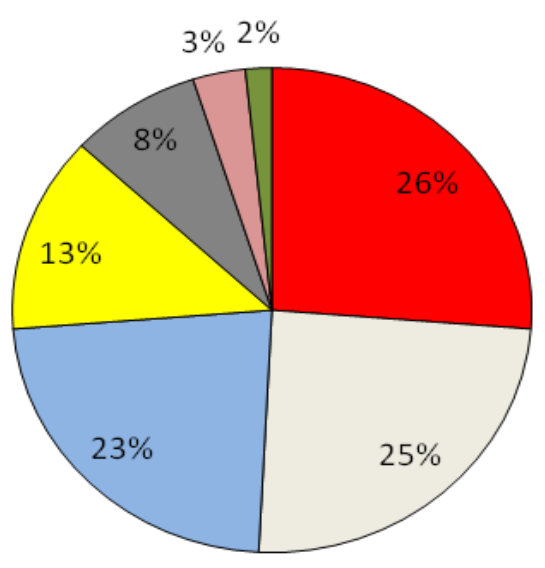

$\square \mathrm{Al} \square \mathrm{ND} \square \mathrm{IB} \square \mathrm{Al}+\mathrm{BB} \square \mathrm{Al}+\mathrm{ND} \square \mathrm{IB}+\mathrm{ND} \square \mathrm{Al}+\mathrm{ND}+\mathrm{BB}$

Fig. (8): Percentage of detected respiratory viral infections in relation to the number of positive samples. 


\section{DISCUSSION}

Respiratory tract infections are of paramount importance in poultry industry and causing high morbidity and mortality in poultry farms throughout the world (Ahmed at al., 2009). A wide variety of pathogens have been associated with respiratory infections in poultry, including AIV, IBV, NDV and ILTV. Mixed viral infections are usually observed in poultry farms; as one or more viruses are involved in the respiratory complex that makes it difficult to determine the main viral causative agent which produces sever disease (Rafiei et al., 2009). Therefore, a multiplex polymerase chain reaction (mPCR) technique that simultaneously detects and differentiates the four major avian respiratory viruses will be highly advantageous to the poultry industry and would greatly aid in the diagnosis and control of outbreaks.

This study was undertaken to develop and evaluate a mPCR for the detection of AIV, NDV, IBV and ILTV in field samples taken from chickens of various outbreaks in Kafrelsheikh governorate during the period from October 2011 till February 2013. The mPCR in the present study was able to amplify nucleic acid of AI, ND, IB and ILT viruses in one single reaction. Similar technique was developed and standardized by Pang et al., (2002) who used mRT-PCR for detection of 6 avian respiratory pathogens, with specific primers for IBV, AIV, ILTV, NDV, Mycoplasma gallisepticum (MG) and Mycoplasma synoviae (MS). Also Yashpal et al., (2004) reported the development and evaluation of a single-tube multiplex RT-PCR (mRT-PCR) assay for simultaneous and specific detection of Avian Pneumo virus (APV), AIV, and NDV. The mRT-PCR assay was found to be as sensitive and specific as sRT-PCR which also agreed with our study. 
To validate the use of these mPCR assays in field samples, it was applied on 100 field samples collected from broiler and layer chicken flocks suffering from severe respiratory signs and relatively high mortality in Kafrelsheikh governorate. The mPCR was successfully able to detect and differentiate single and mixed infections with two or more viruses in a single reaction. The total number of positive samples was 61 out of 100 examined samples (61\%). The number of samples with single viral infection was 45 with a percentage of $45 \%$ from total samplesand $73.7 \%$ from positive samples while number of samples with mixed viral infection was 16 (16\% from total samples) and (26.3\% from positive samples). The result of high percentage of mixed infections was similar to that obtained by Pang et al., (2002); Ahmed et al.,(2009); Tao et al., (2009); Yashpal et al., (2004); Rashid et al.,(2009); Roussan et al., (2008) and Rafiei et al., (2009) who reported that the etiology of the respiratory disease is complex, often involving more than one pathogen, which makes it difficult to determine the main viral causative agent which produces severe disease. These mixed infections may occur due to extensive use of multiple live vaccines, high geographic populations and housing densities (Pang et al., 2002), despite the use of IBV, NDV and AIV vaccines, it is common to find NDV, IBV and AIV infections in vaccinated broiler flocks (Mehrabanpour et al., 2011). AIV was evidenced in $30 \%$ of the examined samples with percentage of $49.1 \%$ from positive samples which was in accordance with Hegazy et al., (2011) and Omar et al., (2011) who noted that AIV remains one of the greatest health concerns for both human and poultry and they suggested an endemic situation of AIV in Egypt. In 14 samples AIV were 
combined with other viruses (8 samples co infected with IBV, 5 with NDV).Similar results were obtained by Tao et al., (2009); Farkas et al., (2007); Mehrabanpour et al., (2011) and El Zowalaty and Goyal (2011) who reported that co-infection of AIV and NDV occurs frequently in field cases .Our results of frequent cases of AIV and IBV co-infection agreed with that of Haghighat-Jahromi et al., (2008) and Seifi et al., (2009). IBV infection was evidenced in $25 \%$ of examined samples, which reflects the endemic nature of the disease as described by (Mahgoub et al., (2010) and Lebdah et al., (2004). Despite the regular vaccination programs in chicken farms mostly with Mass H120 strain (Hoda et al., 2013); IBV still has a severe adverse effect on the poultry industry. Concerning NDV, the total number of samples positive for NDV was 23 out of 100 collected samples with a percentage of $23 \%$ from total samples and $37.7 \%$ from positive samples which was similar to that obtained by Mohamed et al., 2011 who reported that ND outbreaks occur frequently in Egypt.

The present study is conclusive with the fact that the etiology of respiratory organisms is very complex usually involves more than one pathogen. Based upon the results obtained in the present study, this mPCR assay for simultaneous detection of AIV, IBV, NDV and ILTV, could be a useful instrument for rapid screening and surveillance in wild and domestic birds. Furthermore, it is also concluded that AI, IB and ND viruses are wide spread among broiler and layer chicken farms in Kafrelsheikh governorate, despite the vaccination effort and the strict biosecurity measures being employed which lead to severe respiratory disease or they predispose to secondary bacterial infection after suppression of the chicken's immune system. 


\section{REFERENCES}

- AbdEl-wahab, E. M. and Hafez, H. M. (2011): An overview of the epidemic of highly pathogenic H5N1 avian influenza virus in Egypt: epidemiology and control challenges, Epidemiology and Infection, 139, pp 647-657.

- Ahmed, A.; T.A. Khan; B. Kanwal, Y.; Raza, M.; Akram, S.F.; Rehmani, N. A. and Kazmi, S.U.( 2009): Molecular identification of agents causing respiratory infections in chickens from southern region of Pakistan from October 2007 to February 2008. Int. J. Agric. Biol325-328

- Ali, A and Reynolds, D.L.(2000): A multiplex reverse transcriptionpolymerase chain reaction assay for Newcastle disease virus and avian pneumovirus (Colorado strain). Avian Dis.; 44(4):938-43.

- Callison,S.A.;HiltD.A.;Boynton,T.O.;Sample,B.F.;Robison,R.;Sway ne,D.E.and Jackwood,M.W. (2006): Development and evaluation of real time taqman RT-PCR assay for detection of infectious bronchitis virus from infected chickens.J.Virol.Methods138:60-65

- El Naggar, A. Ibrahim, A.(2005): Case study of the Egyptian Poultry Sector World Journal of Poultry Science ;61(3):491-514

- El Zowalaty, M. and (Author) Goyal, S. (Author) (2011): Avian Influenza diagnosis: Virus isolation and real time RT-PCR

- Farkas,T.; Antal,M.; $\quad$ Sa'mi,L.; Germa'n,P.; Kecskeme' t,S.; Kardos,S.; Bela'k,S. and Kiss,I.(2007): Rapid and Simultaneous Detection of Avian Influenza and Newcastle Disease Viruses by Duplex Polymerase Chain Reaction Assay. Zoonoses Public Health. $5438-43$ 
- Haghighat-Jahromi, M.; Asasi, K.; Nili, H.; Dadras, H.and Shooshtari, A.H.(2008): Coinfection of avian influenza virus (H9N2 subtype) with infectious bronchitis live vaccine. Archives of Virology April 2008, Volume 153, Issue 4, pp 651-6

- Hegazy, A. M.; Abdallah, F. M.; Abd-El Samie L. K. and Nazim, A. A.(2011): The Relation between some Immunosuppressive Agents and Widespread Nature of Highly Pathogenic Avian Influenza (HPAI) PostVaccination. J. of American Science; 7(9):66-72

- Hoda, I.T; Ekram, S.; Ola, M .H. and Amal A. (2013): Preparation and evaluation of live bivalent infectious bronchitis vaccine in chicken. Researcher; 5(3):31-35

- Lebdah, M. A.; Eid, A. A. M.; El-Shafey, A. M. (2004): Infectious bronchitis virus infection among meat-type chickens in Sharkia Province (Egypt). International symposium on avian corona- and pneumovirus infections, Rauischholzhausen, Germany, pp. 75-86

- Mahgoub,K.M.; Bassiouni, A.A.; Afify, M.A.and Rabie,N.S. (2010): The Prevalence of Infectious Bronchitis (IB) Outbreaks in Some Chicken Farms. I. Spotlight on the Status of IB Outbraks in Some Chicken Flocks. Journal of American Science; 6(9)

- Mehrabanpour, M.J.; Rahimian, A. ; Shoshtari, A.H.; Fazel, P.D. Kariminejhad, E. and Moazeni Jula, G. R. (2011): Molecular Identification of Avian Respiratory Viral Pathogens in Commercial Broiler Chicken Flocks with Respiratory Disease in Shiraz-Iran

- During 2009-2010. International Journal of Animal and Veterinary Advances 3(5): 300-304 
- Mohamed, M.H.; Kumar, S.; Paldurai ,A.; Megahed, M.M.; Ghanem, I.A.; Lebdah, M.A. and Samal, S.K. (2011): Sequence analysis of fusion protein gene of Newcastle disease virus isolated from outbreaks in Egypt during 2006. Virology Journal, 8:237

- Omar,D.M.; El-Ibiary,E.A.; Sadik,A.S. ; Abdel-Ghaffar,M.H. and Othman,B.A. (2011): Serological and Molecular Identification of Some Isolated Avian Influenza Viruses During Outbreaks in Egypt. International Journal of Virology, 7: 123-134.

- Pang,Y.; Wang,H.; Girshick,T.; Xie, Z. and Khan,M.I. (2002): Development and Application of a Multiplex Polymerase Chain Reaction for Avian Respiratory Agents. Avian Diseases: Vol. 46, No. 3, pp. 691-699.

- Rafiei, M.M.; Vasfi-Marandi, M.; Bozorgmehri-Fard, M.H. and Ghadi, S. (2009): Identification of Different Serotypes of Infectious Bronchitis Viruses in Allantoic Fluid Samples with Single and Multiplex RTPCR.Iranian Journal of Virology 3(2): 24-29.

- Rashid, S.; Naeem, K.; Ahmed, Z.; Saddique, N.; Abbas, M.A.and Malik, S.A. (2009): Multiplex polymerase chain reaction for the detection and differentiation of avian influenza viruses and other poultry respiratory pathogens. Poult Sci. vol. 88, pp. 2526-2531.

- Roussan, D.A.; Haddad, R.and Khawaldeh, G. (2008 b): Molecular Survey of Avian Respiratory Pathogens in Commercial Broiler Chicken Flocks with Respiratory Diseases in Jordan. Poult Sci. vol. 87, pp. 444-448. 
- Seifi,S.;Asasi, K. and Mohammadi, A.(2009): A study of natural coinfection caused by avian influenza H9 subtype and infectious bronchitis viruses in broiler chicken farms showing respiratory signs. Journal of veterinary research; 13 (1):53-62

- Siddique, N.; Khalid, N.; Ahmed, Z. and Akbar, M. S. (2008): Evaluation of RT-PCR for the Detection of Influenza Virus Serotype H9N2 among Broiler Chickens in Pakistan Int. J. Poult. Sci., 7 (11): 1122-1127.

- Spackman, E.; Senne, D.A.; Myers, T.J.; Bulaga, L.L.; Garber, L.P.and Perdue, M.L (2002): Development of real-time reverse transcriptase PCR assay for type A influenza virus and the avian H5 and H9 haemagglutinin subtypes.J.Clin.Microbiol. 40:3256-60

- Tao,Q.; Wang,X.; Bao, H.; Wu,J.; Shi,L.; Li,Y.; Qiao,C.; Yakovlevich,S.A.; Mikhaylovna,P.N. and Chen,H.(2009): Detection and differentiation of four poultry diseases using asymmetric reverse transcription polymerase chain reaction in combination with oligonucleotide microarrays. J. Vet. Diagn. Invest. 21:623-632.

- Yashpal,S.M.; Devi, P.P. and Sagar, M.G.(2004): Detection of three avian respiratory viruses by single-tube multiplex reverse transcription polymerase chain reaction assay. J. Vet. Diagn. Invest. 16: 244-248.

- Xie,Z.; Pang,Y.; Liu,J.; Deng,X.; Tang,X.; Sun,J. and Khan,M. (2006): A multiplex RT-PCR for detection of type A influenza virus and differentiation of avian $\mathrm{H} 5, \mathrm{H} 7$, and $\mathrm{H} 9$ hemagglutinin subtypes Mol Cell Probes. Jun-Aug; 20(3-4):245-9 
مسح جزيئي على الأمراض التنفسية الفيروسية في الدواجن في محافظة كفر الثيخ

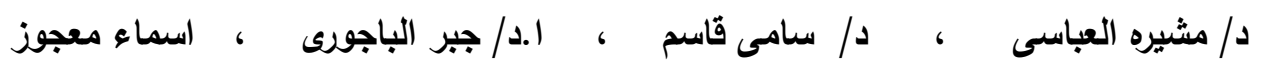
تعتبر الأمراض التتفسية من أكثر الأمراض انتشارا في مزارع الدجاج فى مصر مسببه خسائر اقتصاديه كبيره نتيجة لنقص الإنتاج الداجني من اللحم الأبيض والبيض. ومن أهم الفيروسات المسببة للأمراض التتفسية فى الدجاج فيروس إنفلونزا الطيور، فيروس النويكاسل، فيروس التهاب الثعب الهوائية المعدي وفيروس التهاب الحنجرة والقصبة الهوائية المعدي فى الدجاج. وغالبا ما يكون سبب المرض هو

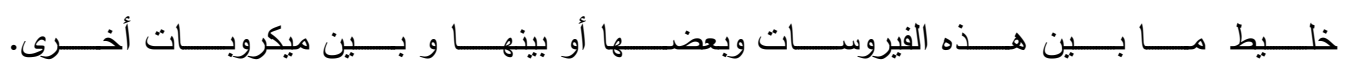
وقد صممت هذه الدراسـة لنطوير اختبار تفاعل البلهرة المنسلسل المتعدد للكثَف عن وجود هذه الفيروسات الأربعة في اختبار واحد وذلك باستخدام بوادئ عامه للكثف عن الحامض النووي الخاص بهذه الفيروسات. أثتتت الدراسة أن هذا الاختبار قادر وبنجاح على تحديد والتفريق بين هذه الفيروسات سواء كانت العدوى فرديه أو مختلطة وذللك باستخدام بوادئ عامه للفيروسات الأربعة. وللكثف عن مدى نجاح وفاعليه هذه الاختبارات عند تطبيقها على العينات الحقلية، فقد تم تجميع 100 عينه (رئة وقصبه هوائيه) من مزارع دجاج مصابه بأعراض تتفسيه ونسب نفوق عاليه من مناطق مختلفة فى محافظه كفر الثيخ. وأظهرت النتائج أن نسبه الإصـابة الكلية بهذه الفيروسات الأربعة 61\% وقد وجد أن الإصـابة الفردية بنوع و احد من هذه الفيروسات كان 45\% بينما نسبه العدوى المختطة بنوعين أو ثلاثة كان 16\% نسبه الإصابة الكلية بفيروس إنفلونزا الطيور كانت 30\%و بفيروس النيوكاسل 23\% وبفيروس التهاب الثعب الهوائية المعدي 25\% بينما لم يتم تشخيص فيروس التهاب الحنجرة والقصبة الهوائية المعدي في هذه الدراسة. 